\title{
Riders to the Sea between Regionalism and Universality: A Cultural Perspective
}

\author{
Amal Riyadh Kitishat \\ Department of English Language and Literature, Ajloun University College, Al Balqa’ Applied University, Ajloun, \\ Jordan
}

\begin{abstract}
This study aims at discussing Synge's Riders to the Sea, with a focus on Irish nationalism and cultural identity as two significant ways of resistance against the English cultural colonialism. Though many critics regard J.M. Synge as an example of a regional dramatist because his works are related to the local Irish material, this study; however, aims to correct this vision of Synge as only pertaining to Irish Celtic culture, but as an innovator of the Irish theatre and as a culturalist who shifted Irish theatre into a universal scope. Thus, though Synge's fame is due to his treatment of the "folk" drama; still, he finds in Ireland's folk tales, myths, and traditional legends a rich source for universal interests. By tracing the reinforcement of the Irish setting and oral culture for a cultural function which aims at establishing the Irish identity and reviving its national heritage, the study argues that Synge's dramatic presentations were not only of regional or local value; but also, of international and cultural significance. That is though J.M. Synge introduces his theme in a local Irish context, with a focus on peasants; he was able to transform the Irish theatre from the local context to universality.
\end{abstract}

Index Terms - Riders to Sea, modern Irish theatre, J. M. Synge, naturalistic drama, nationalism and cultural identity

\section{INTRODUCTION}

John Millington Synge is best known for his treatment of Irish myths and folktales within a realistic context. His dramatic works glorify the Irish themes; in his plays, he celebrates the imaginative attitude of life realistically by depicting the Irish peasants' life. Synge has dealt with Irish themes especially those which are concerned with the Irish tradition and heritage. The study aims at presenting a thematic study of Riders to the Sea as a representative of colonial literature; this is due to Synge's important role in the reviving of the Irish cultural identity which was achieved by his drawing on the Irish culture as a major source for his plays. He finds in Ireland's legends, folklore, and fairy tales a rich source of his masterpieces' themes.

The study aims at presenting a thematic survey of the national dimensions presented in Riders to the Sea as a literary de Anglicization of the Irish cultural identity. Synge plays a significant role in the Abbey Theatre. It was his presence in the Abbey that made the Irish Dramatic Movement has its peculiar Irish feature. It is his way in introducing the Irish drama that shapes a new dramatic style for generations of Irish dramatists.

\section{SYNGE'S VISION OF DRAMA}

Synge's place in modern Irish drama is unique since there is no any writer deserves this status expect him. For example, Kitishat (2012) stresses the peculiarity of Irish theatre if compared with other European theatres. She argues that Synge plays a vital role in de Anglicizing Irish theatre; his role in employing the Irish material to revive Irish culture to establish a dependent Irish identity is of great cultural value. Kitishat justifies this attitude as a" distinctive features of the Irish theatre because it adopted and reintroduced the Irish habitat as a tactic which aims to "strengthen national feelings among the audience." (Kitishat, 2012, p.83). Besides, there is a close and inseparable relationship between Irish culture and national attitudes. Therefore, this tendency is considered an "invisible restriction" on Irish Theatre." (Pilkington, 2004, p. 724) This sense of nationalism plays a significant role in the Irish nation pursuit of having their independence and refusing the colonial rule of their country.

Synge shows a different attitude toward politics from other Irish writers; although he lives in a period of political and cultural extremity, he prefers to work for his country cause in his ways. He explains his political attitudes saying, "I wish to work in my way for the cause of Ireland."(Benson, p. 1) He chooses to give a real Irish setting which depicts the Irish reality as a way of rejecting the English literary influence on the Irish theatre. Al -Ghoreibi (2015) sees such representation of the Irish setting "renders the natives insular and untouched by the modernizing influences of British colonialism" therefore such representations are considered as "representatives of the pre-colonial Irish culture."( pp.1112) This tendency of glorifying the Irish material as a way of cultural resistance against the English colonial and literary hegemony makes Synge as one of the distinctive Irish writers in the Irish dramatic movement because of his reintroduction of the Irish habitat to strengthen the national feelings and establish a distinct Irish Identity among the 
audience. So, this over-determined relation between the theatrical, cultural and historical matters has, Pilkington argues, "pervasive "functions (Pilkington, 2004, p.724)

Synge considers the dramatists' role of great importance since they are responsible for directing people to the right way, yet he does not tend to idealize his country. Nevertheless, he introduces his country in a very realistic manner. He expresses the dramatists' responsibility in a way which is different from other Irish dramatists in his time; he says" [A] writer's first duty to his country is disloyalty. "(qtd. In Ferriter, 2004, p. 174). By disloyalty, he means the responsibility of "presenting Ireland as he found her, not as she wished to be found."(qtd. In Ferriter, 2004.p.174) It is apparent then that this is the distinctive feature that makes Synge different in his handling of the Irish myths and traditions in his dramatic works. Thus, it is Synge who manages successfully to employ the Irish legend for local and universal purposes simultaneously.

\section{Synge's PEASANTS' DRAma: From Regionalism to UniVERSALITy}

It is recognized that Synge is interested in the realistic details of his society. His dramatic treatment of Irish life gives his plays a local quality, he went to the Aran Islands and lived among the islanders and depicted their dialects and gathered much knowledge about the oral culture and heritage. This experience provides him with the raw material for the sources of his plays, with regard to this point, Collins calls this style as "cottage kitchen realism; he states that "Synge's dramatic treatment of life in Aran Islands is symptomatic of that hackneyed (but trendy) style that was peculiar to the Abbey Theater's formative years."(Collins, 2015, p.13) Moreover, Synge includes both the negative and positive characteristics of his society, and since no one laughed at his own mistakes, Irish people find a huge gap between them and a genius writer as Synge. Synge was different from the playwright in his age due to his awareness of "two differential realities" and at the same time is concerned with "how they could be made to dovetail seamlessly within his dramaturgical praxis." (Collins, 2015, p. 14) However; Synge shared with Yeats his interest in the poetic imagination. Synge believes that the poetic use of language is still living among the people of Ireland. Therefore many critics have discussed Synge's poetic, dramatic language; for instance, Fermor elaborates that Synge was exceptional because of his use of poetic drama. (Ferriter, 2004, p.163).

Fermor's opinion above indicates the difficulty of the separation between Synge's poetic and dramatic expressions. So, one can say that Synge can be identified as "a dramatic poet." It is necessary hence to point, in specific terms, to Synge's poetic language about the "peasants Drama." Synge is a poet who has used peasants' living idioms and folk speech in a poetic form. Synge's use of poetic drama is because of his belief that the roots of his poetry are in "mysticism." (Ibid) Many of his heroes and heroines act and speak exactly in a way similar to those peasants who live in the Irish Islands. This is since he lives among those peasants and depicts their language, beliefs and "mystic" vision of life. He cares a great deal about his poetic language a true drama since this quality makes his plays "magnificent." (Price, 1961, p. 45).

This perspective of dramatic language, Eliot argues, makes the works of Synge as a highly-appreciated model of a poetic drama, "poetic both in imagery and in rhythm." (Eliot, 1953, p.32). This attitude is to some extent true because Synge has described the beautiful intonation and diction of the peasants' talk in his book Aran Islands. In this book, Synge offers a complete record of the people's way of life.

It is Synge who introduces the Irish peasants' drama; in this dramatic school by highlighting the life of ordinary people: tinkers, drunkards, braggarts, tramps, cowards, hypocrites and even patricides. He writes about their lives sympathetically as well as satirically. He chooses those ordinary people to talk about this category of people who are oppressed by society especially by priests and political authorities. He sheds light on the "plight of men and women who existed in a meaningless world." (Benson, 1982,p. 1).

It is suitable in this context to give a brief an account of Synge's religious beliefs and his view of religion in general. What attracts the attention is Synge's earlier loss of faith. In his autobiography he justifies his attitude toward religion by stating that he had renounced Christianity, to be a believer only in Ireland!. "Everything Irish became sacred." (Gregory, 1972, p. 43)

Therefore, he is obsessed with that conflict between the freedom of the individual and supernatural beliefs. Many of the writers of his age reject Christianity and adopted other ideologies, perhaps the most well-known dramatist who share this quality with him are Yeats and O'Casey. The conflict between paganism and Christianity is represented in Irish gods and mythical heroes and heroines. On the other hand; Christianity is portrayed in priests, saints, and clergymen. Synge's use of the Irish material may be attributed to that advice that Yeats has given to Synge. While Synge was studying in Paris, he met Yeats who advises him to do the following. In Essays and introductions, Yeats recommends Synge to leave France and to go back to Ireland, to The Aran Islands, in particular, to live among the people there and to learn rural expressions because Yeats believed that they "express a life that has never found expression. "(Yeats, 1961, p.96)

Yeats directed Synge to the correct literary career, and so, Synge visits Aran Island five times between 1898 and 1901 every summer. In each visit, he shares peasants' joy tales, legends that are derivate from the Irish mythology. Synge also describes their language regarding diction and tone [...], which differ entirely from the other parts of Ireland. Naturally, The Aran Island is organized in four sections; in every region, he records what he has gathered in his summer visits to The Aran Islands. The narrative follows in a chronological way (Green, 1994, p. 22). Synge benefits from his 
visits a great deal; it is evident than that Synge gets the dialect which has become his feature mark from his visits to the Aran (Ibid). Also, much of his mythical material is seen from that legendary folk tales that Irish peasants have mentioned. He writes about his experience in The Aran Islands and how it inspires him as a playwright because he depicted real peasants' "dialect and dialogue" as a material for his play. (Price, 1961, p.47)

Benson (1982) considers Synge's work as important as The Prelude. He argues that when Synge makes his visits to The Aran Islands, he does not have a definite theme or any writing mechanism. This book is not to be considered as travel books for Synge assure us in his introduction of The Aran Islands that this book includes nothing about the historical or geographical information about the Island. In this regard, he is seen as a "diarist," who was very "selective" and managed successfully to express in great literary professionalism the islanders' life, in a great realism away from artificiality. (Benson, p. 25).

Synge's experiment in The Aran Islands encourages other dramatists to look closely at the Irish society; the urban as well as the rural. Linguistically speaking, the speech of Irish peasants in The Aran Islands gives Synge "a linguistic model for which he had been vainly searching in Paris, a model a datable under its range and power to his urgent sense of life." (Deane, 1994, P. 29). During that period, Synge spent much of his time studying Irish mythology and culture. He masters the old Gaelic language and participates in reviewing many Irish books written by Irish writers. For example, he examines The Irish Mythology Cycle and Celtic Mythology.

\section{SyngE's DuALity: A SOURCE OF INNOVATION}

When Synge starts writing his plays, he combines two essential elements: they are the tragedy and comedy; heroism and anti-heroism, mythic and comic. The duality is apparent in his works, and this fact makes him a distinguished playwright. Hence, the audience will realize that "Satiric laughter" is embodied in many of Synge's characters.

Grene points to Synge's attempts in introducing a new drama saying. He argues that Synge has liberated his comic characters from the stereotypes of national idealism; by introducing his comic characters from the rural part of Ireland. Synge does not idealize heroes, kings or even poets, on the contrary, we find ourselves face to face with ordinary people such as tinkers and tramps. By introducing them, we know the real world with it is hardship and ugliness. The combining of the comic and mythic is of great importance because the repressed emotions can find a kind of outlet in the legends of laughter that spring from the nation's folk imagination. (Krause, 1995, p. 18)

Also, Synge indirectly relates the comic impulse to the mythic impulse in their secondary function of release. Both were considered as an outlet of "unconscious aspirations, our private desires that are frustrated in the conscious or public world." (Krause, 1995, p. 18) Taking this fact into consideration, one can realize what kind of challenge that Synge faces when he employs the comic and mythic or the mock-heroic way of writing. He admits that he must overcome that difficulty that is aroused from the combining of these mythic elements with the comic drama. Saddle Myer (1971) maintains that Synge's experience in The Aran Islands was an exciting and challenging experience, "full of new difficulties, and I shall be the better, I think for the change." (p. 167)

\section{The Treatment of Myth in RIDERS to the SEA}

Riders to the Sea is best- defined ad Synge's first "accomplished work of a master craftsman.” (Grene, 1975, p. 41) Some critics classify it as a "folk drama" since it drew its strength from that pagan mood of fatalism that dominated the events. (Casey, 1994, p. 89) In this play, the combining of the world of myth and reality is seen and converted realistically to give a universal theme.

The play can be just summed up as the story of a family who lost most of it is members in their struggle with the sea. The plot is straightforward; the play begins by providing the needed information as s background: Maurya, the heroine of the play, has already lost her husband, her father -in law and four other sons in their struggle with the sea. Her two daughters at the beginning of the first act are trying to identify the clothes of a drowned man as their brother's Michael who has gone to the sea and did not come back. Their attempts at defining the clothes are interrupted by the appearance of their mother; this makes them hide the clothes for a short period to conceal the tragic fact from her. It is at that moment when their youngest and last brother "Bartley" enters preparing himself for a journey by the sea. The mother tries to prevent him from going, but he insists on leaving. The moment has left the house, but she has a kind of mystic vision, then she says, "He's gone now, God spare us." she even cries: "We'll not see him again." (Synge Riders of the sea, 1958, p. 37) After Bartley's departure, the daughters identify the clothes of the drowned man as Michael's. Later they knew that Bartley was drowned in the sea, too. In the final scene of the play Maurya, the mother mourns the death of her family and invokes mercy on the living and those who are dead.

\section{Paganism and Christianity in Riders to the SEA: An EndLess Conflict}

The material of Riders to the Sea is mainly realistic; however, it deals with that kind of suffering and hardship the fishermen face in their struggle with the seas. The central incident in this play is taken from Synge's experience on his last visit to Aran Island in 1901. (Benson,1982, p.9) In his third chapter of The Aran Island Synge reports an incident which is exceedingly relevant to the play's central episode. 
One night as a hurricane was howling, Norah, a young married woman, was dying of typhus, as she was not expected to live beyond the morning, coffin boards had to be borrowed from a man who had put the board aside two years before his aged mother. The headless body of a and young man had been washed ashore after floating for several weeks in the sea, and once again kenning hammering could be heard in the vicinity of the awake cottage. The young man had taken a Curragh to two horses from a hooker to the shore of the South Island., and the young man was lost, [...] but his mother also had a vision of him riding a horse to the slip, she saw him catch his horse, then a second horse and afterward he went out and was drowned. (Synge,1970, pp. 416-17)

Hence, it is clear that the plot of Riders to the Sea is of a significant degree of similarity with the episode that reported in The Aran Islands. His use of the folk-tales in his play shows the high degree of influence the peasants' life and beliefs had on him. Also, there are many mythical elements that Synge has handled in his writing of the play for instance, we are told that if a living man were seen in a company with a dead man this would be considered as a bad omen because that is a gesture to the fact that this man is going to die. This kind of superstitious belief is prevalent among those Irish peasants.

In addition to this point, Mary C. King discusses this idea with a special reference to Riders to the Sea; the cause of tension that dominates the play can be attributed to the co-presence of both pagan and the Christian beliefs, and this is the gap that the Islanders seek to bridge. (King, 1985, p.48). Synge stresses this theme in many episodes of the play. For example; at the beginning of the first act while Maury was trying to prevent her son from going, she said that "the young priest will stop him surely."'(Synge, 1958, p.36). However, Nora, her daughter, objected her saying that the priest said that Al-Mighty God would protect Bartley because he is Maurya's last remaining son!. Therefore, because of this reason the priest did not prevent Bartley from going to sea; or even advising him not to go. However; we later know that he was drowned and Maurya lost all her family with her fight with the sea. By giving this unexpected end, the young priest is presented as a powerless and weak man in comparison with the eternal sea.

Some critics suggest the death of Bartley is a "bitter testimony to the immeasurable cruelty of the god of The Aran Islands." (Benson, 1982, p.25). It is Maurya who Knows the sea well "it is little the like of him knows the sea [...] Bartley will be lost now."(Synge Riders of the sea, 1958, p.37) Synge highlights the mythical setting of the play, by introducing another incident when Maurya forgets to give Bartley a piece of cake, a symbol of life, and hence decides to look for him before going far away, it is at the moment when she sees "the fearfulness thing"-her dead son Michael riding a gray horse and Bartley following him. It is worth connecting this episode with the original mythical story. In his Aran Islands, there are many stories about horses in all cases they were related to the supernatural. The source of the "grey horse "episode was one of the stories that Synge recorded. He narrated the story as he heard it. (Synge, 1970, $p$. 418)

Although there is a difficulty in dramatizing events that include supernatural elements such as ghosts, second sight, Synge was able to overcome them since the Irish audiences still believe in mythical stories about such events. The grey horse riders in the folk - stories, on According to the belief of the peasants, horses in general; and grey horses in particular from a mythical perspective, represented death and mystery. (Synge, 1970, p. 418). This justifies why Maurya shouted in fear when she saw her dead son, comes seeking his brother.

In this play, Synge celebrates the life of the individuals, especially those Irish peasants, who exist in a tragicomic world within "a nihilistic universe" that offered neither meaning nor hope. (Benson, p. 152). So, though Synge has used the Irish myth as the source for his play, yet he enlarges it to include a universal truth. The central theme is death in counter with life. Maurya in her final speech blesses the dead as well as the living. Her blessings included all humanity in the face of that fate is waiting for it.

In other words, the writer succeeded in illuminating the kind of life the inhabitants had to live. In this play, Synge realistically depicts the life of the Irish fishermen and that sense of fear of the sea, and it is waves. Maurya declares that she is triumphant over the sea after the death of her sons and husband; the sea cannot do anything for her, she does not care for it surfs any longer. She laments the death of her family. She says she had lost her husband and her father in law and six young sons in her struggle with the sea.

The play is a mixture of a realistic kind of life that is combined with mythical and pagan powers. For example, the setting of the play is wholly depicted in a realistic way from the ordinary life of the Islanders. The setting is dominated by nets, a spinning - wheel, new boards. These tools are used in every day of the Irish peasants' life. They are also useful in their symbolic significance. Daniel Casey supported this opinion saying that "the symbols, echoes, and allusions are archetypal; they are drawn directly from a primitive folk engaged in the most elemental struggle, the struggle for survival in nature" (Casey 1994:93). Moreover, the colors that Synge used are of significant indications: the black, white gray and red, all of them are associated with death and destruction. The somber mood of the people's life is dominated by the blackness of night, of the cliffs [... ] (Casey, 1994, p.94).

By focusing on "the marginalized people," Synge was able to put the" details of the material and cultural impoverishment of life among the most marginalized in remote rural Ireland."(Mathews 2009: 10). Thus, taking all these details within the historical and cultural dimensions of the play proves the great national role played by Synge who managed successfully to document the oral culture into literary documented sources which prevented the loss of these valuable sources of ancient Pagan Irish culture. This achievement reminds us of his declaration that "I wish to work in my way for the cause of Ireland." In all of Synge's plays, "he champions the imaginative life and condemns 
whatever seeks to restrain human liberty" (Benson, 1982, P. 1). Therefore, Synge succeeds in upgrading the Irish material and "blending" it into a universal scope (Uddin, 2016, p.171). The use of myth gives us a universal impression of the play such as the themes of the vain fewer efforts made by man to avoid death. In other words, Synge succeeds in transforming the Irish material of his play into a universal scope.

\section{CONCLUSION}

Synge succeeds in transferring the Irish peasants' life from a realistic depiction into a universal worldwide appeal; He was able to revive Irish national identity by reintroducing Irish myths and folktales as source material for his plays. Adding to the Irish regional myths and tales related universal themes especially those related to human freedom and liberty, Synge was able to modernize Irish material and share it universally. However, Synge maintains to have the Irish themes clear in all of his works, but at the same time, they indicate serious matters that are of universal interests. In Riders of the sea, Synge celebrates the life of the individuals, especially those Irish peasants, who exist in a tragicomic world within a nihilistic vision of man pessimistic life which has no hope and full of conflict and contradictions. So, it is this vision of the modern Irish man as a weak creature in the pre-colonial Ireland, and he seems weak, unarmed against the English Colonial literary hegemony in addition to other external factors. Synge succeeds in achieving multipurpose function; the first is of a cultural aesthetic value which is manifested in his using the Irish Celtic sources of the precolonial Ireland as a source of most of his plays. This task is of great significance because of its culture as well as national significance. It functions as fire back against the English colonial hegemony over the Irish literature and the colonizer's claim that the Irish are without culture or heritage. Synge was able to bring the ancient Celtic material of the pre-colonial Ireland back to life. Not only this, but he was also able to foster the loyalty and sense of nationalism of the Irish people because they have a great living culture. Also, Synge importance transcends the regionality of the Irish theatre; his treatment of the material was so brilliant that it had transformed Synge's drama to universality since it includes universal truth and thus has a universal appeal.

\section{REFERENCES}

[1] Al - Ghoreibi, Fathi. (2015). The troubled Irish mother Figure in J.M.Synge's Riders to the Sea and Tom Murphy's Bailegangaire. Umm Al -Quora University journal of Languages and literature,15(1) Retrieved on January 10, 2018, from://https://drive.uqu.edu.sa/https://www.questia.com/library/journal/1P3-3901847121/this-world-of-inarticulate-power-j-msynge-s-riders_/jll/files/15/6.pdf.

[2] Benson, Eugene. (1982). J.M Synge. Dublin. Gill and Macmillan.

[3] Price, Alan (ed). (2014). Synge and Anglo-Irish Drama. London: Macmillan.

[4] Burk, Mary. M. (2016). The Riot of Spring: Synge's 'Failed Realism' and the Peasant Drama. Invited Synge and Stravinsky chapter for the Oxford Handbook of Modern Irish Theatre. Oxford: Oxford University Press.

[5] Casey. Daniel. (1994). An Aran Requiem: Setting in Riders to the sea. Critical Essays on John Millington Synge. New York: Maxwell and Macmillan.

[6] Collins, Christopher. (2014). Synge and 'protestant comedy: For the sake of sanity: doing things with humor in Irish performance. Cary for Press: Dublin.

[7] Collins, Christopher. (2015). 'This world of inarticulate power': J.M. Synge's Riders to the sea and magical realism. In: Beyond realism: Rodopi experimental and unconventional Irish drama since the revival. QDR studies in literature (56). Amsterdam, Pp. 13-27.

[8] Collins, Christopher. (2016). The Cries of Pagan Desperation: Riders to the Sea. In: Theatre and Residual Culture. Palgrave Macmillan, London.

[9] Darin, Doris. (1946). Sean O'Casey. New York: Frederic Unger Publishing Co.

[10] Eliot, T. S. (1953). Selected Essays. London Faber, and Faber Limited.

[11] Ferriter, Diarmuid. (2004). The Transformation of Ireland.New York, NY: Overlook Press.

[12] Gregory, Augusta Lady. (1972). Our Irish Theatre. New York: Colin Smythe Ltd.

[13] Green, H. David. (1994). J.M. Synge A reappraisal.Critical Essays on John Millington Synge . New York: Maxwell and Macmillan.

[14] Grene, Nicholas. (1975). Synge: A Critical Study of the plays. London: Macmillan.

[15] Jacobs, Gertrude. (1962). Dictionary of Mythology, Folklore, and Symbol. New York: Scarecrow Press.

[16] King, Mary C. (1985). The Drama of J.M. Synge. London: Fourth estate.

[17] Kitishat, Amal Riyadh. (2012). Colonialism and the recreation of identity: The Irish Theatre as a case study." Journal of Language and Culture. Vol. 3(5). Pp. 83-86.

[18] Krause, David. (1982). The Profane Book of Irish Comedy. Ithaca: Cornell Un. Press.

[19] Krause, David. (1984). The Risen O'Casey: Some Marxist and Irish Ironies. O'Casey Annual 3. London: Macmillan.Pp134168.

[20] Mathews, P.J.(ed.). (2009). The Cambridge Companion to J.M. Synge. Cambridge: Cambridge. Un. P.

[21] Pilkington L. (2004). Historicizing is not Enough: Recent Developments and Trends in Irish Theatre History. Modern Drama, Winter, XLVIII, 4: 721-731.

[22] Price, Alan, ed. (1961). Collected Works of J.M. Synge. Vol. IV, London: Macmillan.

[23] Saddlemyer. (1971). Ann Letters to Molly: John Millington Synge to Maire O'Neill. Massachusetts: The Harvard University Press.

[24] Synge. J. M. (1970). The Aran Islands. Oxford: Oxford University. 
[25] Synge. J. M. (1981). "Riders to the Sea" in Four plays and the Aran Islands. Oxford: Oxford University.

[26] Synge. J. M. (1985). The collected plays of J.M. Synge. London: Macmillan.

[27] Uddin, Mohammad Jashim and Md. Ferdous Iqbal Chaudhary. (2016). Patriarchal Dominance in J. M Synge's Riders to The Sea: Viewing from a Feminist Perspective. Journal of Human and Social Sciences. 21(11): Pp.04-09.

[28] Yeats, W.B. (1961). Essays and Introductions. London: Macmillan.

Amal R. Kitishat (Correspondent author): born in Salt city/The Hashemite Kingdom of Jordan in 26 of May 1970. She obtained a Ph.D. in English literature from Cairo University in 2006. She is a specialist in modern and contemporary drama. She is an Associate Professor of English Literature, a specialist in contemporary and modern English \&Irish drama. Formerly, she held the position of Head of Department of English Language and Basic Sciences at Al Balqa Applied University \Ajloun -Jordan. Currently she is a staff member in Faculty of Arts and Head of Scientific Research Unit. Her interests in scholarship include Orientalism, English and Irish drama and literary criticism; she has published many books and articles in the field of English literary studies.

Dr. Kitishat is a member in many literary professional societies such as ALECSO - Arab League Educational, Cultural and Scientific Organization which belongs to the Arab League. Dr. Kitishat is a referee for many academic journals as well as a representative for the department of English in the Deanship of Scientific Research Unit in Faculty of Arts. 